\title{
PODER JUDICIÁRIO NO JULGAMENTO DE LITÍGIOS POLÍTICOS, SOCIAIS E MORAIS ORIUNDOS DA OMISSÃO LEGISLATIVA E EXECUTIVA
}

\author{
Lidiane Melo de Souza ${ }^{1}$ \\ Monica Fontenelle Carneiro ${ }^{2}$
}

\section{RESUMO}

O presente estudo pretende analisar a existência de limites na atuação do Poder Judiciário no julgamento dos litígios políticos, sociais e morais oriundos da omissão legislativa e executiva na perspectiva de que nenhuma lesão ou ameaça a direitos poderá ser afastada da apreciação do Poder Judiciário. Em termos metodológicos, o presente trabalho pauta-se basicamente na pesquisa bibliográfica. Discorre sobre o princípio da separação dos Poderes na transição do Estado Liberal para o Estado Social e a transformação do abstencialismo judicial em intervencionismo. Examina o papel político dos juízes e o controle da decisão judicial através da racionalidade jurídica.

Palavras-chave: Separação dos Poderes. Omissão Legislativa e Executiva. Intervencionismo Judicial. Racionalidade Jurídica. Garantia de Direitos.

\section{JUDICIAL POWER IN THE JUDGMENT OF POLITICAL, SOCIAL AND MORAL DISPUTES FROM THE LEGISLATIVE AND EXECUTIVE OMISSION}

\begin{abstract}
The present study intends to analyze the existence of limits in the Judiciary's performance in the judgment of political, social and moral disputes arising from legislative and executive omission in the perspective that no injury or threat to rights can be removed from the Judiciary's appreciation. In methodological terms, the present work is basically based on bibliographic research. It discusses the principle of the separation of Powers in the transition from the Liberal State to the Social State and the transformation of judicial abstentialism into interventionism. It examines the political role of judges and the control of judicial decisions through legal rationality.
\end{abstract}

Keywords: Separation of Powers. Legislative and Executive Omission. Judicial Interventionism. Legal Rationality. Guarantee of Rights.

\section{INTRODUÇÃO}

\footnotetext{
1 Mestranda do Programa de Pós-Graduação em Direito e Instituições do Sistema de Justiça da Universidade Federal do Maranhão (UFMA). E-mail: E-mail: lmelo12345@ hotmail.com.

2 Professora Doutora e Mestre em Linguística pela Universidade Federal do Ceará (UFC). Professora do Departamento de Letras - DELER - e do quadro permanente dos Programas de Pós-Graduação em Letras PPGLETRAS (Campus de São Luís) e PPGLB (Campus de Bacabal) da Universidade Federal do Maranhão (UFMA). Professora colaboradora do PPGDIR - Programa de Pós-Graduação em Direito da Universidade Federal do Maranhão (UFMA).
}

Revista de Processo, Jurisdição e Efetividade da Justiça | e-ISSN: 2525-9814 | Encontro Virtual | v. 6 | n. 2 | p. 01 - 17 | Jul/Dez. 2020. 
Não é difícil de perceber que, não só atualmente, mas ao longo da história, o Poder Judiciário tem sido muito aplaudido e também bastante criticado por suas tomadas de decisões, especialmente quando estas envolvem questões de cunho político, de implementação de políticas públicas ou escolhas morais em temas controversos na sociedade.

Considerando que o Poder Judiciário faz parte da tríade de Poderes contemplados pela Constituição Federal, juntamente com os Poderes Legislativo e Executivo, sendo esses independentes e harmônicos entre si, cumpre esclarecer que cada Poder tem suas funções típicas e atípicas.

O princípio da separação dos Poderes impõe restrições ao Poder Judiciário, estabelecendo como sua função típica a interpretação e respeito às leis (em sentido amplo), ou seja, o limite de suas atribuições é dado exatamente pelo ordenamento jurídico. Nesse sentido, o Poder Judiciário deve trabalhar baseado na legislação para o exercício da sua função típica de resolução dos conflitos, que deve ser realizada pela observância das normas.

De outra banda, é função do Poder Judiciário resguardar os direitos fundamentais dos indivíduos para que nenhuma lesão ou ameaça a direitos, em especial os direitos consagrados na Constituição, possa ser afastado da sua apreciação, por ser considerado o guardião da Constituição Federal.

Ocorre que algumas questões de grande repercussão política ou social estão sendo resolvidas pelo Poder Judiciário, e não pelas instâncias políticas tradicionais, como Congresso Nacional e Poder Executivo. Essa circunstância decorre do modelo constitucional que se adotou, e não de um exercício deliberado da vontade política.

O Poder Judiciário é devidamente provocado a se manifestar e o faz nos limites dos pedidos formulados, não tem a alternativa de conhecer ou não das ações, de se pronunciar ou não sobre o seu mérito, uma vez preenchidos os requisitos de cabimento. Não há uma opção ideológica ou filosófica do Judiciário, pois esse decide em cumprimento, de modo estrito, ao ordenamento jurídico vigente.

Ao decidir as questões políticas, sociais e morais que envolvam os Poderes Legislativo e Executivo e a sociedade civil, principalmente quando nessa relação as demandas não estejam sendo atendidas efetivamente, o Poder Judiciário, quando provocado, tem uma participação mais ampla e intensa na concretização dos fins constitucionais, com maior interferência no espaço de atuação dos outros poderes. 
Partindo dessas premissas, o objetivo deste trabalho é responder à seguinte problemática: Há limites na atuação do Poder Judiciário quando provocado para decidir sobre litígios políticos, sociais e morais oriundos da omissão legislativa e executiva?

Compreendemos que um aprofundamento dessa questão pode ajudar a esclarecer as possíveis consequências institucionais relacionadas à superação da subsunção e do seu impacto sobre o princípio da separação dos Poderes, bem como sobre a imposição de limites à atuação do Poder Judiciário.

Trata-se de um tema que recomenda maior investigação científica no intuito de produzir alternativas eficazes para a adequação do Poder Judiciário à sua função constitucional, notadamente no tocante à solução dos litígios políticos, sociais e morais não resolvidos pelos Poderes Legislativo e Executivo.

No presente trabalho, pretende-se examinar a existência de limites impostos à atuação do Poder Judiciário no cumprimento do seu dever de julgar, quando provocado para enfrentar os litígios políticos, sociais e morais oriundos da omissão legislativa e executiva, considerando a aplicação de uma hermenêutica jurídica expansiva, antecipando-se, algumas vezes, à formulação da própria lei.

\section{ALÉM DA SEPARAÇÃO DE PODERES}

Historicamente, a técnica da separação dos Poderes pressupunha que o exercício do poder, que antes era concentrado em um só órgão, deveria ser dividido entre vários órgãos. A concentração, cujo maior exemplo correspondia anteriormente à monarquia absolutista, foi a primeira forma de exercício do poder. Era uma forma inconveniente, porque dava margem ao arbítrio. Assim, a necessidade de prevenir o arbítrio levou à limitação do Poder por meio da distribuição do seu exercício. O Poder do Estado é uno e indivisível, assim como também é una e indivisível a soberania. Entretanto, o exercício desse Poder pode ser distribuído entre órgãos do Estado, o que não rompe a unidade do Poder. Isso porque o que se divide não é o Poder, mas sim o seu exercício. Portanto, divisão de Poder quer dizer divisão de exercício do Poder, divisão de trabalho.

O princípio da separação dos Poderes, como uma das bases do constitucionalismo, implica fixação de limites e de objetivos ao exercício do poder político. Tem, portanto, três principais sentidos. O primeiro, de controle recíproco entre as instituições, por meio de um 
sistema de freios e contrapesos, em que o Poder freie o Poder, impedindo abusos. O segundo, o sentido de organização política, por meio da atribuição das funções de elaborar a lei, de exercer o governo e de dizer o Direito, fixando competências e padrões de interação entre os órgãos. E, por fim, o terceiro sentido que é garantir direitos, por meio da obediência ao padrão objetivo de justo, estabelecido na Constituição e aferido pelo Judiciário, por meio do controle de constitucionalidade.

A separação dos Poderes representa um limite ao Executivo, ao Legislativo e ao Judiciário, respectivamente em suas funções de governo, legislação e jurisdição. Esses limites têm por finalidade estabelecer uma relação de independência e equilíbrio no exercício de cada uma dessas funções. Há uma semelhança entre a adoção da separação dos Poderes e as etapas históricas do constitucionalismo. Isso porque, assim como a Constituição surge da dicotomia entre absolutismo e constitucionalismo, cujos fundamentos foram os mesmos, também, a separação dos Poderes provém dessa relação de forças entre as instituições, assim como da ideia de organização política e de garantia dos direitos.

Logo de início, a separação dos Poderes tinha por finalidade garantir direitos. Entretanto, esses direitos correspondiam tão-só à liberdade individual, valor típico a ser protegido no momento em que nasceram, no Estado Liberal de Direito, tanto o princípio da separação dos Poderes quanto a própria Constituição. Esse processo se iniciou na Inglaterra do século XVII, potencializou-se na França e nos Estados Unidos da América, no século XVIII e, a partir de então, repercutiu pelo mundo. Assim, no Estado Liberal, a Constituição e a separação dos Poderes nasceram com o mesmo propósito de garantir liberdade individual.

É preciso considerar que a ideia de Constituição, assim como a própria concepção de Estado, evolui com o tempo. Isso porque, especialmente nos séculos XIX e XX, foi reconhecido o papel social, na correção das injustiças geradas pelo Estado Liberal. Com isso, o Estado Social, além de proteger a liberdade individual, ou melhor, até mesmo para proteger essa liberdade, incumbiu-se de promover os direitos sociais. As Constituições incorporaram, portanto, os direitos sociais no rol dos direitos fundamentais.

O século XX experimentou uma valorização da Constituição enquanto base jurídica dos Estados e como instrumento de garantia dos direitos fundamentais da pessoa humana. Agora, é possível dizer que, no século XXI, o constitucionalismo será caracterizado pelo humanismo ativo. A história da humanidade será marcada pela revalorização do Direito, agora visto como instrumento de harmonização, bem como de realização da Justiça e da Paz. 
O Estado de Direito nasceu liberal em sua essência, caracterizado, nos séculos XVIII e XIX, pela abstenção como requisito para proteção de direitos, já que, segundo essa antiga visão, a intervenção na sociedade deveria ser mínima, apenas para assegurar as condições de liberdade nas relações humanas. Ocorre que a ausência de limites ao poder econômico, típica do liberalismo, gerou grandes desigualdades sociais que ensejaram um novo modelo de Estado, assim chamado Estado Social de Direito, caracterizado, nos séculos XX e XXI, pela intervenção como forma de promover igualdade e direitos sociais, necessários para proteção da dignidade humana e promoção do bem comum, finalidades típicas do próprio Estado.

Na passagem do Estado Liberal para o Estado Social, o papel desempenhado pelo Judiciário também evoluiu. $\mathrm{O}$ abstencionismo judicial transformou-se em intervencionismo. Reconheceu-se, também, o papel político dos juízes para garantia dos direitos sociais (LASSALLE, 2007).

O princípio da separação dos Poderes, por sua vez, acompanhou essa evolução. A garantia de direitos inspirada na nova separação dos Poderes não corresponderá apenas à contenção de um Poder por outro, a fim de proteger a liberdade individual. A nova separação significará também a intervenção ou a cooperação entre os Poderes a fim de garantir a igualdade material e os direitos sociais. Por essa razão, a separação dos Poderes permite que o Judiciário garanta direitos sociais contra omissões do Executivo e do Legislativo (LASSALLE, 2007). ${ }^{3}$

Segundo Mancuso (2001, p. 738-739), “[...] todo esse contexto vai evidenciando que não há como sustentar o argumento de que a sindicabilidade judicial sobre as políticas públicas implicaria ingerência indevida do judiciário, assim atritando a separação entre os Poderes",4.

Por isso, uma das caraterísticas do Estado Social será justamente a intervenção a fim

\footnotetext{
3 Nesse sentido, Dallari (1963, p. 134) afirma que “[...] são três aquelas funções fundamentais, ou seja, a legislação, a execução, que compreende administração e governo, e a jurisdição, as quais devem estar separadas e manter independência recíproca, não obstante atuem em plena harmonia e cooperação, valendo-se umas dos órgãos mais afetos às outras, sempre que isto seja recomendável em vista do objetivo almejado. [...] Por esta fixação mais precisa de atribuições - que não deve chegar à rigidez mecânica - cada órgão poderá tornar-se mais apto e mais adequado ao cumprimento da função que o solicitar, o que, afinal, resultará em maior eficiência e direção mais justa, no exercício das atividades do estado". No mesmo sentido, Mancuso (2001, p. 731) escreve que, “[...] a evidente 'interação' e 'complementaridade' entre as funções e atividades do Estado contemporâneo mostra a sem-razão do argumento que (ainda) pretende erigir a clássica separação dos poderes em obstáculo à ampla cognição, pelo Judiciário, dos questionamentos sobre as políticas públicas”.

4 “[...] não é, pois, de se descartar a hipótese de que a propalada contraposição entre política pública e controle judicial talvez mesmo configure, no limite, um falso problema, ou menos uma 'falsa antinomia', a se ter presente que os princípios constitucionais têm de ser compatibilizados entre si, para conviverem harmoniosamente, sem que um esvazie o conteúdo ou enfraqueça a eficácia do outro; assim, é com esse espírito 'largo' e 'conciliador' que se deve ler os princípios da independência entre os Poderes e o da garantia de acesso à Justiça” (MANCUSO, 2001, p. 743).
} 
de promover direitos. E, para que isso aconteça, é previsível a interferência de um Poder no papel que seria tipicamente do outro, caso ocorra uma violação aos direitos. É preciso aproximar, então, novamente a separação dos Poderes da ideia de garantia. Nessa nova perspectiva, a separação dos Poderes não será empecilho para que um Poder fiscalize o cumprimento do papel constitucional que o outro Poder deve exercer ${ }^{5}$.

Dallari (1998, p. 222) afirma que a exigência de maior dinamismo e de presença constante do Estado na vida social "[...] é incompatível com a tradicional separação dos Poderes"; bem como defende "[...] que se reconheça que o dogma da rígida separação formal está superado, reorganizando-se completamente o Estado, de modo a conciliar a necessidade de eficiência com os princípios democráticos".

Por tudo isso, se, no passado, separação dos Poderes representava abstenção para proteger a liberdade individual, agora, no presente, simboliza intervenção para promover também igualdade material, com o objetivo de, num futuro próximo, construir sociedades humanistas e democráticas, principal finalidade do constitucionalismo. Essa nova separação dos Poderes, mecanismo de realização da Justiça e da Paz, não mais constitui garantia ao Poder, mas sim garantia aos direitos.

A transição do Estado Liberal para o Estado Social retratou a valorização da igualdade material em relação à liberdade individual. Por isso, ao Estado não mais coube somente proteger os direitos individuais, porque, como resultado dessa transição, a ele caberá também promover os direitos sociais, por meio de ações governamentais. Essa evolução gerou, da mesma maneira, uma nova atuação do Poder Judiciário, que assumiu seu papel político, bem como passou a desempenhar um intervencionismo judicial. Portanto, espera-se hoje que o Legislativo e o Executivo cumpram seu papel na realização dos direitos sociais, bem como que o Judiciário fiscalize ativamente o cumprimento dessa obrigação estabelecida pela Constituição. Nesse cenário, a concepção de separação de Poderes também se modificará.

Pela Constituição atual, os direitos sociais são exigíveis e justificáveis. A realidade do Brasil atual revela que, graças à Constituição de 1988, muitas injustiças foram eliminadas,

\footnotetext{
5 Dallari (2002, p. 1) reconhece a necessidade da atualização do princípio da separação dos Poderes, ao constatar que: "Os três Poderes [...] estão inadequados para a realidade social e política do nosso tempo. Isso pode ser facilmente explicado pelo fato de que eles foram concebidos no século dezoito, para realidades diferentes, quando, entre outras coisas, imaginava-se o 'Estado mínimo', pouco solicitado". E ensina que: "o Supremo Tribunal Federal está [...] obrigado a decidir quando impetrada uma ação em que se alega desrespeito à Constituição ou à lei [...]. Ele não apenas pode mas deve decidir, sem que isso configure [...] quebra do princípio da separação de Poderes" (DALLARI, 2006).
} 
entretanto, evidencia, também, que muito ainda precisa ser feito para a plena efetividade dos direitos sociais.

A Constituição de 1988, no artigo $2^{\circ}$, consagra o Judiciário como um poder independente, bem como o reconhece, nos termos do artigo $5^{\circ}, \mathrm{XXXV}$, como o poder capaz de garantir os direitos sociais contra ameaças e violações. Por isso, no Brasil atual, o princípio da separação dos Poderes, tal como expresso na Constituição, não impede que o Poder Judiciário garanta direitos sociais, porque essa garantia é uma decorrência do próprio princípio.

Nossa história recente registra que predominou a exaltação pelo Poder Público unicamente do sentido político de Constituição. As consequências foram a negação de força normativa à Constituição, bem como a assunção de uma postura neoliberal. Por isso, no Brasil pós-1988, afiguraram-se “omissões inconstitucionais" tanto em legislar quanto em governar a favor dos direitos sociais (DALLARI, 2002).

As omissões do Poder Público ensejaram uma postura mais ativa do Poder Judiciário sobre quem recaiu a demanda social gerada pelo abstencionismo. Ocorreu aquilo a que se chamou de "judicialização da política". Ou seja, em outras palavras, ocorreu uma grande procura pelo Poder Judiciário a fim de que ele solucionasse o problema social gerado pelo neoliberalismo. O resultado foi que o Poder Judiciário ressaltou o sentido jurídico de Constituição. Assumiu uma postura intervencionista de afirmação da força normativa, atitude a que se chamou "ativismo judicial". Então, esse ativismo judicial, nada mais é do que uma resposta natural às demandas sociais geradas pelas omissões dos outros poderes (DALLARI, 2002).

Isso porque o principio da separação dos Poderes, consagrado no Brasil pelos artigos $2^{\circ}$ e $60, \S 4^{\circ}$, III da Constituição Federal de 1988, há de ser interpretado em conformidade com o princípio da inafastabilidade da jurisdição, consagrado no art. $5^{\circ}, \mathrm{XXXV}$ da mesma Constituição.

Portanto, não há como dizer que a separação dos Poderes impede a garantia de direitos. Isso porque ela própria já é uma garantia institucional aos direitos. Garantia de direitos, mas não garantia de Poder, já que o princípio da separação de Poderes não pode servir como uma justificativa para que os Poderes Executivo e Legislativo furtem-se ao juízo do Poder Judiciário, no caso de descumprimento da Constituição.

A evolução do Estado Liberal para o Estado Social refletiu-se na compreensão que se 
tem acerca do princípio da separação dos Poderes. Isso porque a garantia de direitos inspirada na nova separação dos Poderes não corresponderá apenas à contenção de uma função por outra a fim de evitar ingerência daquela na vida concreta do cidadão, protegendo a liberdade individual. Significará também a intervenção de uma função em outra a fim de garantir que a omissão seja efetivamente suprida, promovendo a igualdade material.

Diante da inércia do Legislativo em regulamentar algumas normas constitucionais, dificultando que elas surtissem efeitos na vida concreta dos cidadãos, ou, no caso de inércia representada pela omissão do Executivo em, por exemplo, promover educação, saúde, alimentação, trabalho, moradia, lazer, segurança, previdência social e todos os direitos sociais, sob a justificativa de que não há recursos econômicos para tanto, seria correto impedir que o Judiciário garantisse direitos, sob o argumento de que ele não tem o batismo do voto popular ou ainda sob o argumento de que, em assim agindo, praticaria uma invasão à esfera dos demais Poderes?

Portanto, é possível dizer que, no Brasil atual, o princípio da separação dos Poderes não opõe limites à garantia de direitos sociais pelo Judiciário contra omissões do Executivo e do Legislativo, tendo em vista que a separação dos Poderes é concebida como garantia de direitos (LASSALLE, 2007).

Agora, quando o Judiciário avoca-se da sua condição de poder independente, capaz de defender o Direito e a Justiça, em especial contra omissões dos outros poderes, muito se contesta. Especialmente por meio da dicção de que o Judiciário está sendo ativista, que está extrapolando sua atribuição. Por certo, a garantia de direitos feita pelo Judiciário jamais poderá constituir um transbordamento de atribuições, até mesmo pela atual compreensão que se tem do princípio da separação dos Poderes. Para que esse princípio seja mesmo respeitado, muitas vezes não bastará apenas a abstenção do Poder ou do órgão, mas, muito além disso, será necessária também a sua intervenção. O mesmo acontece com o Judiciário. Para que exerça a contento a jurisdição deverá, na mais das vezes, levantar-se da sua postura abstencionista e intervir nas inconstitucionalidades dos outros poderes. Ainda mais quando essa intervenção representar garantia de direitos, principal propósito da própria separação dos Poderes.

“Aplicar a lei não significaria mais enquadrar casos concretos em normas abstratas, mas realizar uma série de outras operações mentais que, igualmente, têm como finalidade fazer valer, no caso concreto, as leis postas pelo Parlamento" 
(RODRIGUEZ, 2017, p. 129).

A centralidade no Poder Judiciário é consequência da incapacidade do sistema político tradicional de dar conta da complexidade social traduzidas em demandas dirigidas ao Judiciário, o que fortalece a ideia de que "[...] os juízes têm que ter um papel criativo para que sejam capazes de inovar o ordenamento jurídico, produzindo, através da atividade interpretativa das normas, as respostas aos conflitos sociais" (RODRIGUEZ, 2017, p. 130).

Segundo Rodriguez (2017, p. 132) “[...] fica excluída a pertinência de análises que vejam o direito positivo estaticamente, apenas como texto normativo, sem levar em conta sua elaboração sob a forma de normas e o processo de atribuição de sentido levado a cabo pelas autoridades aplicadoras".

Continua o autor dizendo que "[...] o crescente ativismo judicial olhado, muitas vezes, com desconfiança e classificado como 'judicialização da política', ou seja, como uma usurpação do Poder Legislativo dos representantes do povo, é a contraparte necessária de todo este processo" (RODRIGUEZ, 2017, p. 133). Este processo é o fator sociológico que impulsionou as mudanças do direito, que desorganizaram as estruturas institucionais e dogmáticas que herdamos do século XIX. ${ }^{6}$

Nesse passo, é necessário "[...] pensar a racionalidade jurídica não mais como a aplicação de dogmas definidos pelo sistema político aos casos concretos. A aplicação é um processo de parte das normas, ou melhor, do material jurídico à disposição do juiz, mas não se define pela subsunção" (RODRIGUEZ, 2017, p. 145).

É preciso estudar o direito como estrutura mutável e não como um mecanismo eterno de reprodução da sociedade. As constantes mudanças pelas quais vem passando o Estado contemporâneo coloca em xeque a separação dos Poderes e sua concepção tradicional. Por isso, há a necessidade de se pensar a racionalidade jurídica não mais como a aplicação de dogmas definidos pelo sistema político aos casos concretos, mas como um processo de parte das normas, do material jurídico à disposição do juiz que não se define com subsunção, pois a atividade do julgador restrita à aplicação mecânica

\footnotetext{
6 Nesse sentido, Rodriguez (2017, p. 134-135) afirma que “[...] o formalismo deve ser estudado em conexão com as demandas sociais sempre renovadas, e com as mudanças ocorridas nas sociedades. Caso contrário, estaremos vendo o direito como um elemento neutro e inerte, cujo papel seria o de reproduzir certa formação social, ou seja, certa relação entre classes e grupos sociais, julgada como desejável para todo o sempre. A 'mitificação' da separação de Poderes está estreitamente ligada a este problema".
} 
das normas jurídicas ao caso concreto não dá conta de solucionar os atuais conflitos políticos, sociais e morais que deságuam no Poder Judiciário.

\section{QUEM CONTROLA O CONTROLADOR?}

Uma coisa é dizer, em abstrato, que para um determinado caso concreto é sempre possível imaginar uma solução jurídica diferente, mas daí não se pode deduzir ser impossível qualquer forma de controle interno sobre a racionalidade das decisões.

Não é mais possível pensar a "verdade", assim como o direito, como algo estático, absoluto, mas como uma construção através de uma comunidade plural de intérpretes em conflito. De acordo com Rodriguez (2017, p. 160) “[...] o que importa a um modelo de racionalidade judicial é determinar a maneira pela qual o juiz irá justificar sua decisão, ou seja, quais regras irão presidir a construção do texto de sua justificação" ${ }^{\text {,7 }}$

Trata-se apenas de uma mudança no critério de demarcação entre o direito e as demais ordens normativas. Direito este que passa a funcionar de acordo com um ideal diverso de segurança jurídica. Este ideal reza que sua racionalidade será compreendida de outra maneira, em função do modelo de justificação.

Posta a questão nestes termos e afastada a ilusão de se obter, sempre, uma única resposta correta para cada problema jurídico ou uma justificativa única que fosse capaz de impor faticamente ao campo jurídico um único e mesmo modelo de racionalidade judicial para orientar a atuação de juízes, advogados, promotores, professores, é possível impor algum grau de restrição por outra via, qual seja, padronizando o raciocínio jurisdicional.

Com efeito, para que "[...] um modelo meramente subsuntivo pudesse funcionar bem no Brasil seria necessário fazer reformas institucionais de grande alcance, a começar pela reforma da Constituição e do modo de conceber e redigir nossas leis" (RODRIGUEZ, 2017, p. 165). É difícil negar hoje a evidência de que haja uma pluralidade de modelos hermenêuticos em disputa. Analisando os acórdãos do Supremo Tribunal Federal, se pode constatar uma variedade de modelos de argumentação os mais diversos.

Esta indeterminação essencial ao direito contemporâneo coloca, com efeito, a

\footnotetext{
7 Reforça Rodriguez (2017, p. 161) que “[...] a evolução da teoria da argumentação do século XX e deste começo do século XXI, em que os modelos de racionalidade judicial baseados na retórica, na tópica e na teoria da argumentação abrem mão do ideal de segurança jurídica como resposta correta, na verdade, pode-se dizer que eles procuram alterar o conceito ideal de segurança jurídica, passando a construir regras racionais para a interpretação e aplicação das normas jurídicas".
} 
necessidade de discutir o controle das decisões judiciais. Suprimir a instabilidade, no mundo atual, não passa de uma ilusão bem intencionada ou com pretensões autoritárias. Para fazê-lo seria necessário conferir aos modelos de racionalidade judicial uma base incontroversa, ontológica ou transcendente, e transformar a teoria do direito em um campo de identificação e fiscalização do cumprimento de um modelo de justificação "correto". Ou simplesmente impor coercitivamente aos juízes e à sociedade um único modo de pensar (RODRIGUEZ, 2017).

Além disso, é preciso buscar uma justa medida entre a visão política e a visão jurídica de garantia aos direitos. Isso porque, com o fortalecimento do Poder Judiciário no Brasil, o único limite ao Poder Judiciário seria o próprio Poder Judiciário. A idoneidade do autocontrole ficaria, em muito, dependente da higidez institucional.

Ocorre que não há razão para esse temor. Primeiro, porque a organização judiciária brasileira, por adotar o sistema difuso de controle de constitucionalidade, reparte o seu poder entre os juízes que compõem o Poder Judiciário. Por essa razão, o poder não fica todo concentrado num único órgão. E essa característica, por si só, já representa uma importante proteção contra eventuais abusos judiciais.

No caso brasileiro, temos uma Constituição escrita que permite aferir o nosso padrão objetivo de justo. E não será apenas a confiança na higidez institucional que assegurará que o Judiciário forte aja segundo limites de razoabilidade. Também a certeza de direitos e o padrão objetivo de justo servirão como limites para uma atuação correta e moderada do Poder Judiciário.

O simples temor de abuso da jurisdição não pode autorizar a prostração do Judiciário frente aos outros poderes. Até porque as decisões judiciais são passíveis de revisão pelo duplo grau de jurisdição e o processo é público e corre em contraditório.

O maior problema, nesse ponto, dirá respeito não aos juízes da causa, nem mesmo aos Tribunais em $2^{\circ}$ grau, mas sim aos Tribunais Superiores. Nesse caso, ganhará muita importância o argumento de que uma jurisdição tão fortalecida e ativista não encontrará limites, pelas mãos, por exemplo, do Supremo Tribunal Federal. Até mesmo pelo fato de que os ministros são vitalícios e indicados pelo Executivo com aprovação pelo Senado. Aí a pergunta ganha muito mais importância e complexidade. Quem controla o Supremo Tribunal Federal? (DALLARI, 2010).

Uma primeira resposta é que o Supremo Tribunal Federal será controlado pelo próprio Supremo Tribunal Federal. Isso porque, ao contrário do Executivo, o Supremo 
Tribunal é um órgão colegiado e as chances de ocorrerem abusos em um órgão colegiado são menores do que as de ocorrerem abusos em um órgão monocrático. Isso pode ser comprovado pelas decisões tomadas por maioria e que foram proferidas após participação da sociedade e debates entre opiniões contrárias no próprio Tribunal. Além disso, valerão para os processos do Supremo Tribunal Federal as mesmas normas de "accountability" aplicáveis a todos os processos judiciais, em especial a necessidade de fundamentação das decisões e a observância ao devido processo legal (DALLARI, 2010).

Uma solução justa nem sempre corresponderá à expectativa do pleito, mesmo porque será imparcial. Tal decisão não constituirá favorecimento, nem mera contrapartida pelo voto. Uma decisão que contemple o interesse da coletividade e não especificamente o interesse de um único grupo ou de uma única pessoa, ainda mais se esse interesse do grupo ou da pessoa contrariar o interesse de toda a coletividade. Uma decisão proferida segundo critérios de racionalidade, por alguém tecnicamente selecionado e capaz de se sensibilizar com a humanidade presente em cada pessoa. Uma decisão fundamentada e que obedeça ao padrão objetivo de justo, expresso pela Constituição. Uma decisão tomada às vistas de todos, a partir de um processo público e democrático.

Por certo, tanto Legislativo quanto Executivo estarão sempre vinculados à Constituição, mas o que é importante destacar é que o exercício do seu poder será feito na medida em que cada um deles julgar conveniente e oportuno, podendo ser, até mesmo por isso, exercido "ex officio". E esse juízo de conveniência e oportunidade poderá muitas vezes justificar indevidamente ações e omissões que contrariem a Constituição, caso em que ensejará a atuação do Judiciário.

Ocorre que, ao contrário dos outros poderes, o Judiciário não atua de acordo com sua conveniência e oportunidade, da mesma maneira que, em regra, não atua "ex officio". Ao contrário disso, o Judiciário somente age mediante provocação, quando as demandas políticas, sociais e morais não resolvidas são despejadas nos tribunais em busca de amparo e solução, sobretudo quando essas demandas não tenham sido previamente atendidas pelo Poder Público.

Esse princípio da inércia da jurisdição bem afasta o sentido negativo do ativismo judicial, porque o ativista é aquele que pratica o ato ainda que não seja chamado a praticá-lo e o Judiciário somente atua quando alguém dele se socorre buscando provimento, seja para solucionar um conflito individual, com efeitos apenas para as partes, seja para julgar uma 
questão coletiva, com efeitos para todos. Uma vez provocado, não poderá o Judiciário negarse a julgar a questão. E esse julgamento jamais poderá ser rotulado como ativista, ainda que possa contrariar o interesse político dos demais poderes.

Se, por um lado, Legislativo e Executivo atuam "ex officio", por outro lado, o Judiciário somente atua mediante provocação. E essa é uma primeira razão pela qual a jurisdição, ainda que política, visto que constitucional, não poderá ser rotulada de ativista, no sentido pejorativo do termo.

De outra banda, ainda que não estejam batizadas pelo voto popular, as decisões judiciais são, de fato, democráticas, porque proferidas sempre sob o resguardo do "due process of law" e dos demais princípios a ele inerentes, o que permite um ambiente público, democrático e dialético na construção da solução mais justa.

A justa medida da separação dos Poderes será a garantia de direitos, ou seja, o respeito à Constituição, que vincula todos os cidadãos e todos os Poderes. E o Judiciário, ao mesmo tempo em que obedece às normas constitucionais, também as faz valer frente aos outros Poderes e à própria sociedade.

Com efeito,

[...] qualquer concepção de Estado de Direito que atribua ao Parlamento toda a competência para criar normas jurídicas irá defender, por conseguinte, uma visão limitada e restritiva da atuação do juiz, ou seja, uma visão de juiz como servo do texto da lei, seja ela baseada em argumentos arbitrários ou não (RODRIGUEZ, 2017, p. 148).

A existência de um Judiciário conservador e preso ao texto legal seria uma garantia contra o subjetivismo de juízes, dotados de poder para definir quais deveriam ser as regras para disciplinar as relações sociais sem um contato mais estreito com a complexidade dos interesses e problemas sociais. Nessa perspectiva, os juízes não teriam legitimidade política para promover tal contato e, se fizessem isso, arriscariam a segurança jurídica (RODRIGUEZ, 2017).

A racionalidade judicial que deve orientar o raciocínio dos órgãos judiciais, pressupõe um determinado desenho da separação dos Poderes, elemento central do conceito de Estado de Direito. Qual a melhor alternativa para o controle social: política centrada no Parlamento e Judiciário estritamente técnico versus política descentrada, com um Judiciário ativo? 
Como devem atuar os juízes? Como deve ser sua relação com os demais poderes? Que procedimentos ele deve seguir para proferir sua sentença? Que operações mentais ele deve realizar para proferi-la? Como ele deve justificá-la?

Importa refletir sobre a necessidade de criar procedimentos e parâmetros para a atividade jurisdicional que, como qualquer outra função atribuída a um Estado de Direito, não pode ser exercida arbitrariamente.

O desenho institucional do Poder Judiciário pode ser controlado através da sua organização em duplo, triplo, quádruplo grau de jurisdição acompanhado de todo um sistema de recursos para revisar sentenças, disciplinadas por regras de natureza processual. Além disso, quanto ao procedimento decisório, as leis podem impor regras processuais sobre a decisão dos juízes. Por exemplo, “[...] a lei exige que toda sentença seja justificada" (RODRIGUEZ, 2017, p. 156).

Exige, para fins de controle da decisão, que determinadas provas sejam aceitas ou não, além de se impor regras para o seu exame e a apreciação pelo juiz.

\footnotetext{
A ordem de produção das provas, a possibilidade ou não de apresentar em juízo determinada espécie de documento ou depoimento, a criação de meios de prova obrigatórios para certos tipos de fatos (ex. Prova pericial obrigatória para averiguar as condições de trabalho insalubres), podem gerar efeitos nas decisões judiciais (RODRIGUEZ, 2017, p. 157).
}

Segundo Rodriguez (2017) a teoria do direito admite que para cada problema jurídico há várias soluções diferentes, todas elas plausíveis, ou seja, fundadas no direito posto. O critério de escolha é puramente subjetivo. No entanto, isso não significa que não seja possível estabelecer controle da racionalidade dos juízes por meio de constrangimentos institucionais ou pela eventual imposição de um modelo de justificação.

Ao invés de pensar em termos estritamente subsuntivos, Rodriguez (2017, p. 159) admite a possibilidade de construir um critério de racionalidade para as decisões judiciais na “[...] tópica, na retórica e na teoria da argumentação".

Ora, a teoria do direito hoje é, justamente, um campo plural de investigação das diversas bases de justificação presentes numa dada sociedade, relacionadas aos diversos problemas jurídicos que ela enfrenta. Ela também é a verificação da consciência das várias possibilidades argumentativas e a discussão e crítica de seus efeitos sociais, políticos e econômicos: nunca um espaço para discutir "verdade” do direito (RODRIGUEZ, 2017).

Assim, é possível estabelecer limites ao Poder Judiciário através de um modelo de 
racionalidade jurídica capaz de descrever com precisão o padrão de operação do julgador, de acordo com o ordenamento jurídico, deixando a decisão jurisdicional positivada e passível de controle na busca de uma justa medida entre a visão política e a visão jurídica de garantia aos direitos.

\section{CONCLUSÃO}

Em síntese, se pensarmos em nosso mundo como um espaço em que habitam uma pluralidade de indivíduos e grupos com ideologias, crenças e interesses, percebe-se como é difícil fundar o direito, seja o desenho institucional do Poder Judiciário ou os modelos de racionalidade judicial, em uma "verdade" qualquer.

Pois é exatamente a possibilidade de alterar o teor do direito positivo e variar as interpretações do mesmo que confere ao direito tal papel proeminente na estabilização temporária dos conflitos sociais. "A teoria e o direito posto não devem naturalizar o que o desencantamento da sociedade, da moral e do direito tornou mutável e instável. Eles devem apenas procurar encontrar as bases possíveis para uma convivência social não violenta" (RODRIGUEZ, 2017, p. 169).

$\mathrm{Na}$ passagem do Estado Liberal para o Estado Social o papel desempenhado pelo Judiciário também evoluiu. $\mathrm{O}$ abstencionismo judicial transformou-se em intervencionismo. Reconheceu-se, também, o papel político dos juízes para garantia dos direitos sociais.

O princípio da separação dos Poderes, por sua vez, acompanhou essa evolução. A garantia de direitos inspirada na nova separação dos Poderes não corresponderá apenas à contenção de um Poder por outro, a fim de proteger a liberdade individual. A nova separação significará também a intervenção ou a cooperação entre os Poderes a fim de garantir a igualdade material e os direitos sociais. Por essa razão, a separação dos Poderes permite que o Judiciário garanta direitos sociais contra omissões do Executivo e do Legislativo (LASSALLE, 2007).

O constitucionalismo brasileiro nasce liberal e, a partir de 1988, consagra como fundamentais os direitos sociais à educação, saúde, alimentação, trabalho, moradia, lazer, segurança, previdência social, proteção à maternidade e à infância, assistência aos desamparados, bem como todos aqueles direitos necessários à Justiça social, mesmo que implícitos. Pela Constituição atual, os direitos sociais são exigíveis e passíveis de proteção 
judicial. A realidade do Brasil atual revela que, graças à Constituição de 1988, muitas injustiças foram eliminadas, entretanto realça também que muito ainda precisa ser feito para a plena efetividade dos direitos sociais.

A Constituição de 1988, no artigo $2^{\circ}$, consagra o Judiciário como um poder independente, bem como o reconhece, nos termos do artigo $5^{\circ}, \mathrm{XXXV}$, como o poder capaz de garantir os direitos sociais contra ameaças e violações. Por isso, no Brasil atual, o princípio da separação dos Poderes, tal como expresso na Constituição, não impede que o Poder Judiciário garanta direitos sociais porque essa garantia é uma decorrência do próprio princípio.

Ocorre que é preciso buscar uma justa medida entre a visão política e a visão jurídica de garantia aos direitos. E essa justa medida assenta-se exatamente na visão de que "[...] o Judiciário será reconhecido como um fator real de poder, capaz de fazer valer a Constituição frente aos outros Poderes, bem como de cumpri-la ele próprio” (LASSALLE, 2007, p. 23). Separação de Poderes será sinônimo de garantia judicial de direitos sociais.

O argumento de que o Poder Judiciário está impedido de decidir sobre política não procede porque direito e política são indissociáveis e compõem o próprio conceito de Estado, cuja soberania também se expressa por meio da jurisdição. A legitimidade do Poder Judiciário não provém do voto, mas sim da própria Constituição e do caráter democrático e público do devido processo legal.

A separação dos Poderes anda de mãos dadas com a Constituição e, portanto, prestase aos mesmos propósitos de garantia de direitos contra Poder e não de Poder contra direitos. Assim, caso um Poder fira os direitos sociais, ainda que por omissão, ao Judiciário competirá exercer a garantia, em cumprimento à Constituição e ao próprio princípio da separação dos Poderes.

Portanto, em resposta à questão inicial, é possível compreender que o princípio da separação dos Poderes não opõe limites à apreciação pelo Poder Judiciário dos variados conflitos políticos, sociais e morais, quando provocado, ainda que oriundos da omissão legislativa e executiva, tendo em vista que a separação dos Poderes é concebida como garantia de direitos, devendo, para tanto, a decisão judicial proferida ser controlada através da imposição de regras de racionalidade para a interpretação e aplicação das normas jurídicas, estabelecida em função de um modelo de justificação para a escolha da solução considerada a mais adequada para cada caso concreto. 
Não há poder autorizado a agir arbitrariamente. Não é nosso propósito aprofundar o debate sobre a contraposição de uma visão de política restrita ao processo eleitoral versus uma visão que admite uma dimensão política na atuação dos três poderes.

Pretende-se neste trabalho fazer uma reflexão no sentido de que não cabe ao Poder Judiciário, diante das omissões dos Poderes Legislativo e Executivo, agir em termos estritamente subsuntivos, mas, como guardião da própria Constituição, do caráter democrático e público do devido processo legal, para que cumpra a sua função constitucional para a garantia de direitos, sem perder de vista que a solução ao conflito deve estar ancorada na justa medida entre a visão política e a visão jurídica de garantia aos direitos, respeitadas as normas de racionalidade jurídica.

\section{REFERÊNCIAS}

BRASIL. Constituição da República Federativa do Brasil. 13. ed. São Paulo: Saraiva, 2014.

DALLARI, Dalmo de Abreu. A Constituição de 1988: democrática e humanista. In:

Constituição e constituinte. 4. ed. São Paulo: Saraiva, 109-123, 2010.

DALLARI, Dalmo de Abreu. Da atualização do Estado. São Paulo, 1963.

DALLARI, Dalmo de Abreu. Elementos de Teoria Geral do Estado. 20. ed. São Paulo: Saraiva, 1998.

DALLARI, Dalmo de Abreu. Omissões do Legislativo. Jornal do Brasil, Rio de Janeiro, A11, 07 jan.2006.

DALLARI, Dalmo de Abreu. O poder dos juízes. 2. ed. São Paulo: Saraiva, 2002.

LASSALLE, Ferdinand. O que é uma Constituiçãa? 2. ed. Campinas: Russell, 2007.

MANCUSO, Rodolfo de Camargo. A ação civil pública como instrumento de controle judicial das chamadas políticas públicas. In: MILARÉ, Edis. Ação civil pública: lei 7.347/1995 - 15 anos. São Paulo: RT, 707-751, 2001.

RODRIGUEZ, José Rodrigo. Como decidem as cortes? 1. ed. Rio de Janeiro: Editora FGV, 2017. 